\title{
Availability of Health Workers of Promotion and Prevention Services at Public Health Center in Indonesia
}

\author{
(Analysis of Health Sector Workers Research Data 2017)

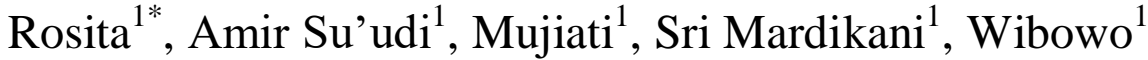 \\ ${ }^{1}$ Center of Health Resources and Health Services Research and Development, National Institute of Health Research and \\ Development, Ministry of Health, Jakarta, Indonesia \\ *Corresponding author. E-mail: aderosi78@gmail.com
}

\begin{abstract}
The strategic plan of Indonesian Ministry of Health (MOH) 2015-2019 targets at least 5,600 Public Health Centers (PHC's) to have five types of promotion and prevention health workers by 2019. These health workers are pharmacy personnel, public health personnel, sanitarian, nutritionist, and medical laboratory technician (MLT's). This study aims to obtain information of the availability and distribution of five types of health workers in PHC's. Methods: The data is processed from the results of the Health Sector Workers Research (Risnakes) in 2017. Design of Risnakes 2017 is cross sectional. The total number of PHC's recorded was 9,699 PHC's. PHC's data grouped by type of health worker into complete PHC's and incomplete PHC's five types of promotion and prevention health. Data analyzed by provinces, population, working area characteristics, health service capabilities, financial management patterns and accreditation of PHC's, and planning of health human resources needs. Results: Data analysis shows that the proportion of PHC's according to the availability of each type of health worker is pharmacy personnel (75,0\%), public health personnel (71.9\%), sanitarian (63.5\%), nutritionist (72.3\%), and MLT's (43.5\%). A total of 1,959 PHC's (20.2\%) in Indonesia have five types of promotion and prevention health workers. According to the provinces, the lowest availability of health workers is North Sulawesi $(2.2 \%)$ and the highest is South Kalimantan $(56.1 \%)$. There is a significant relationship between population, regional characteristics, health service capabilities, financial management patterns and accreditation of PHC's, and planning of health human resources needs with the availability of five types of promotion and prevention health workers in PHC's $(\mathrm{p}=$ 0.000). Need strategies effort for fulfilling health workers starting from the utilization planning stage, including in terms of supervision and evaluation. So that health workers are distributed evenly throughout all PHC's in Indonesia.
\end{abstract}

Keywords: availability, health workers, public health center

\section{NTRODUCTION}

Indonesia is currently faced with a variety of health human resources (HR) issues, including uneven distribution and uneven composition of health workers. [1] The presence of health workers is the key to the success of health service delivery. This is because in the health system, health workers are the main element that supports other health subsystems.[2] The quality of health services depends on the availability, type and number of health workers, which in turn is influenced by policies related to their distribution.[3] Fulfillment of health workers in number, type, and its competence is equally an obligation of the central and regional governments in an effort to ensure the sustainability of health development [4].

Health workers are the driving force of the implementation of health facility services for the community. Public Health Centers (PHC's) is a type of health facility in Indonesia whose distribution covers the district area. PHC's have functions in the implementation of public health efforts (UKM) and firstlevel individual health efforts (UKP). To carry out this function the PHC's organizes health services by prioritizing promotion and prevention efforts [5].

The position of the PHC's in the District / City Regional Health System is part of the district / city health service as the Regional Technical Implementation Unit of the district / city health service. This means that PHC's carry out district / city health service tasks assigned to them, including activities in the District / City Minimum Service Standards (MSS's).[6]. The implementation of MSS's will strengthen the prevention and promotion side of PHC's. District/City Health MMS's consists of health services targeting pregnant women, maternity, newborns, toddlers, basic education age, productive age, old age, people with hypertension, people with diabetes mellitus, people with severe mental disorders, people suspected of 
tuberculosis and people with the risk of being infected with a virus which weakens the human immune system which is all aimed at promoting/promoting and preventing/preventing.[7] Promotion health services are an activity and/or series of health service activities that prioritize health promotion activities. Prevention health service is an activity to prevent a health problem/disease [4].

The activities of promotion and prevention services in PHC's need an important role for health workers who have competence in that field. In the Ministry of Health Strategic Plan (Renstra) for 2015-2019, one indicator of improving the quality of health resources is the PHC's has five types of promotion and prevention health workers. Those health workers are consist pharmacist, public health personnel (PHP's), sanitarians, nutritionist, and Medical Laboratory Technicians (MLT's). The government is targeting that in 2019, the number of PHC's with five types of staff can reach 5,600 PHC'S's . The initial condition of the number of PHC's with five types of promotion and prevention health workers was recorded at 1,015 PHC's, meaning that every year a minimum increase of 917 PHC's with five types of promotion and prevention health service workers is needed, so that the target of 5,600 PHC's in 2019 can be met.[8]

The results of the Health Facility Research (Rifaskes) 2011 illustrates the still limited number of prevention-promotion health workers available at the PHC's.[9] The limitation occurs due to the lack of health workers according to competence or not evenly distributed. This condition makes it possible for health workers to provide services that are not in accordance with their competencies, so that people receive health services that do not meet the standards and do not even receive health services.[10] The purpose of this study is to find out illustrates of availability and distribution of 5 type of promotion and prevention health workers at PHC's in Indonesia.

\section{METHOD}

This study uses secondary data from The Health Workforce Research (Risnakes) of 2017 that conducted by the National Institute of Health Research and Development (NIHRD). The research design is cross sectional survey. The population are 9,699 PHC's in Indonesia. The sample was five types of health workers who served at PHC's throughout Indonesia, consisting of pharmacist, public health personnel (PHP's), sanitarians, nutritionist, and Medical Laboratory Technicians (MLT's).

The data was analyzed based on the distribution of five types of health workers, provinces, residents of work areas, regional categories, financial service pattern and health center accreditation capabilities, as well as HRH planning needs. Data on types of health workers are further grouped into complete PHC's with five types of prevention promotion health workers and incomplete PHC's. Data analysis uses chi square to get a picture of the relationship between variables. Data is presented in tabular and graphical form.

\section{RESULTS AND DISCUSSION}

Based on five types of promotion and prevention health workers, MLT's is the type of health worker who has the smallest ratio, which is 0.7 per PHC's (Table 1). However, there are health centers that do not have pharmacy personnel, public health personnel, sanitarians, nutritionist, and MLT's.

Table 1. Ratio of Health Promotion and Prevention Services per PHC's, Risnakes 2017 (N PHC's = 9.699)

\begin{tabular}{lrr}
\hline \multicolumn{1}{c}{ Types of health workers } & $\begin{array}{c}\text { Sum of health } \\
\text { workers }\end{array}$ & $\begin{array}{c}\text { Ratio per } \\
\text { PHC's }\end{array}$ \\
\hline Public health personnel & 17.877 & 1,8 \\
Pharmacy staff & 13.102 & 1,4 \\
Nutritionist & 10.679 & 1,1 \\
Sanitarians & 9.535 & 1,0 \\
MLT's & 6.525 & 0,7 \\
\hline
\end{tabular}

In 9,699 PHC's sampled in Indonesia, as many as 56.5\% PHC's did not have MLT's, 36.5\% PHC's without Sanitarians, 28.1\% PHC's without PHP's, 27.7\% PHC's without nutritionist, and 25.0\% PHC's which do not have pharmacy personnel (Figure 1).

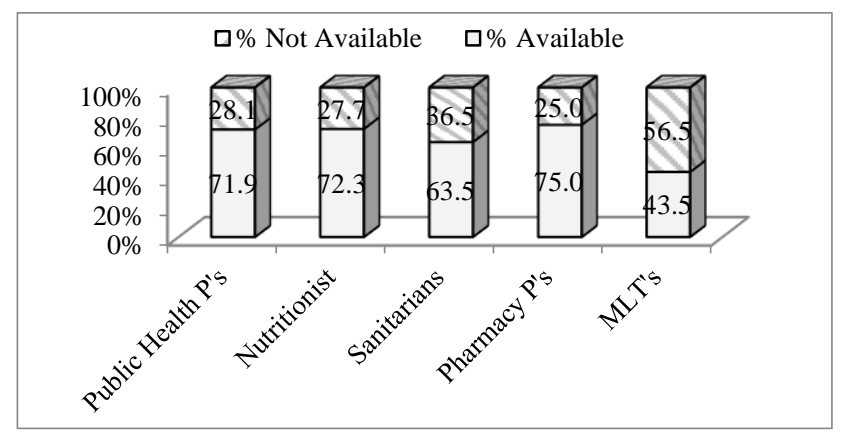

Figure 1. Availability of Health Workers Promotion and Prevention Services at PHC'S's Data Risnakes Results 2017 (N PHC's = 9,699)

PHC's which have promotion and prevention service personnel are said to be complete if they have all five types of health workers consist pharmacy personnel, PHP's, sanitarians, nutritionist, and MLT's. PHC's are said to be lacking if incomplete for the five types of health workers. N complete PHC's have five types of health worker only $20.2 \%$. In other words, there are still around $80 \%$ of PHC's that do not have complete five types of promotionprevention service personnel. Provinces with the highest complete proportion of PHC's had five types of health worker were South Kalimantan (56.09\%), then North Kalimantan (47.83\%) and West Nusa Tenggara (44.3\%). The provinces with the lowest complete proportion of PHC's have five types of health worker are North Sulawesi and Jakarta, which is less than $5 \%$. The presence of 
promotion and prevention health care workers can be seen in Figure 2.

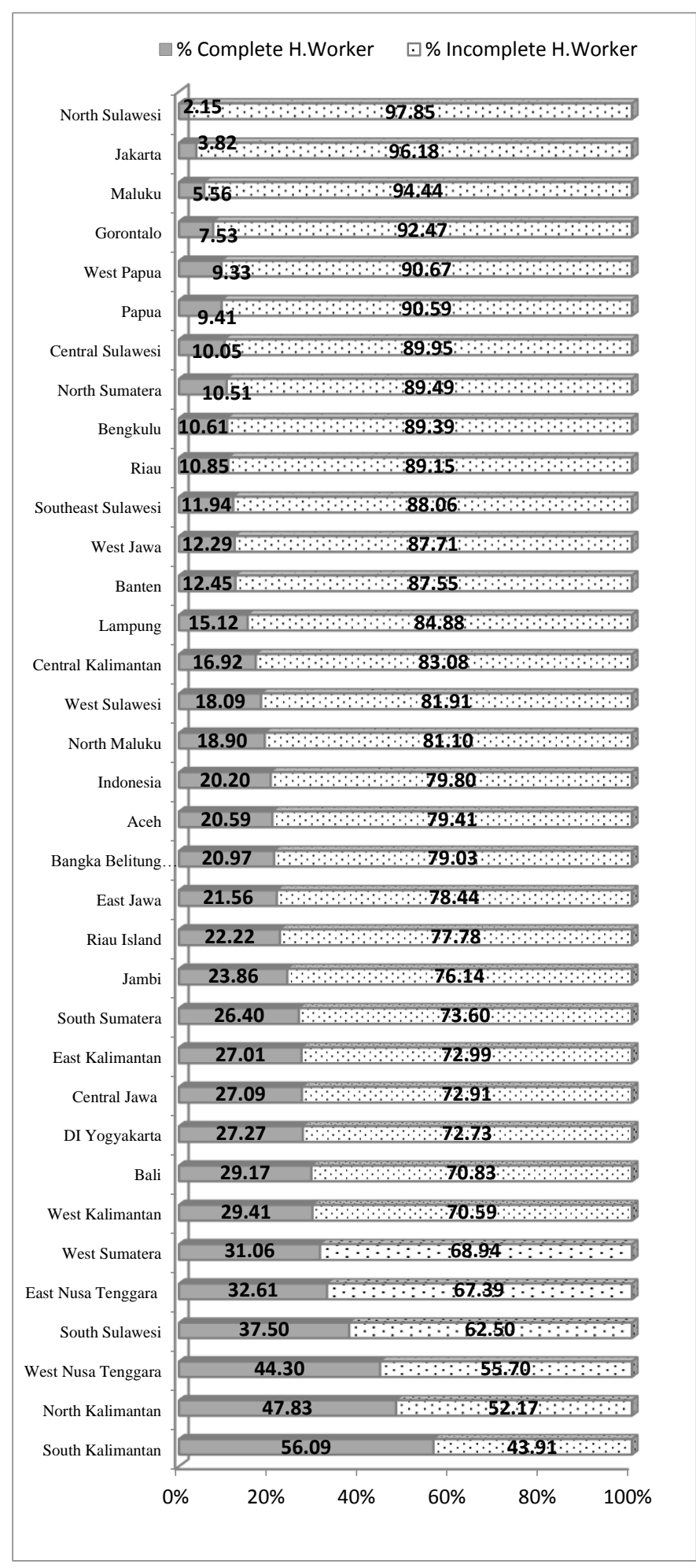

Figure 2. Availability of Health Workers Promotion and Prevention Services in PHC's by Province, Risnakes of $2017(\mathrm{~N}$ PHC's $=9,699)$
The availability of five types of promotion and prevention health workers is more complete in PHC's with population characteristics of more than 30,0000 people, urban areas, inpatient service capabilities, BLUD status, accredited and PHC's that are planning HRK needs. Chi Square test results obtained p-value $0.00(<0.005)$, it means that there is a statistically significant difference between the characteristics of the health center and the availability of fully promotion and prevention health workers.(table 2)

Table 2. Relationship between Availability of PromotionPrevention Health Workers with PHC's Characteristic, Risnakes Of 2017

\begin{tabular}{|c|c|c|c|c|c|}
\hline \multirow{2}{*}{ Characteristic } & \multicolumn{4}{|c|}{$\begin{array}{c}\text { Availability of } 5 \text { types of health } \\
\text { workers }\end{array}$} & \multirow[t]{2}{*}{$P$ value } \\
\hline & Incomplete & $\%$ & Complete & $\%$ & \\
\hline \multicolumn{6}{|l|}{$\begin{array}{l}\text { Population in } \\
\text { working area }\end{array}$} \\
\hline $\begin{array}{l}-\leq 30.000 \\
\text { population }\end{array}$ & 4.902 & 81.4 & 1.117 & 18.6 & 0.000 \\
\hline $\begin{array}{l}->30.000 \\
\text { population }\end{array}$ & 2.825 & 77.0 & 842 & 23.0 & \\
\hline \multicolumn{6}{|l|}{ Area categories } \\
\hline -Urban & 2.100 & 71.7 & 830 & 28.3 & 0.000 \\
\hline -Rural & 4.031 & 82.4 & 860 & 17.6 & \\
\hline - Remote area & 1.609 & 85.7 & 269 & 14.3 & \\
\hline \multicolumn{6}{|l|}{$\begin{array}{l}\text { Services } \\
\text { capabilities }\end{array}$} \\
\hline - Inpatient & 2.827 & 76.0 & 895 & 24.0 & 0.000 \\
\hline - Outpatient & 4.913 & 82.2 & 1.064 & 17.8 & \\
\hline \multicolumn{6}{|l|}{$\begin{array}{l}\text { Financial } \\
\text { management }\end{array}$} \\
\hline $\begin{array}{l}\text { - Regional public } \\
\text { service agency }\end{array}$ & 1.959 & 77.1 & 581 & 22.9 & 0.000 \\
\hline $\begin{array}{l}\text { - Non Regional } \\
\text { public service } \\
\text { agency }\end{array}$ & 5.781 & 80.8 & 1.378 & 19.2 & \\
\hline \multicolumn{6}{|l|}{ Accreditation status } \\
\hline - Accredited & 1.277 & 68.5 & 587 & 31.5 & 0.000 \\
\hline - Not accredited & 421 & 82.2 & 91 & 17.8 & \\
\hline \multicolumn{6}{|l|}{$\begin{array}{l}\text { Mapping of HHR } \\
\text { needs }\end{array}$} \\
\hline $\begin{array}{l}\text { - Developing HHR } \\
\text { needs }\end{array}$ & 6.048 & 78.2 & 1.689 & 21.8 & 0.000 \\
\hline $\begin{array}{l}\text { - Not developing } \\
\text { HHR needs }\end{array}$ & 1.691 & 86.2 & 270 & 13.8 & \\
\hline
\end{tabular}

The Availability of Health Workers Promotion and Prevention Services in Indonesian Health Centers

The main challenge in the delivery of basic health services is the capacity of health facilities to increasing promotion and prevention health efforts, including the availability and development of health workers who support them.[1] The basic health services require promotion, prevention, screening, cure, and rehabilitation services which must give comprehensively and holistically to both community treatment (UKM) and individual treatment (UKP), cannot be only partially. PHC's is a basic health service facility that organizes first-level of community groups and individuals, with more emphasis on promotion and prevention efforts, to achieve the highest degree of public health in the working area.[5]

In 2017, study of National Development Planning Agency (Bappenas) mentions that in the implementation of health services or efforts for the community health services and individual health services cannot be separated. So there is no dichotomy between community health services and individual health services. For example, patient of dengue 
fever need to be treated as an individual, but Aedes Aegypti mosquitoes need to be eradicated by fogging and larval eradication as a community treatment. Patients with hypertension need to be personal treatment, but to eliminate or reduce the incidence of hypertension in the community, needs to be screened and counseled about healthy lifestyle as a community treatment (UKM). However, the description of the differences between community and individual services needs to be understood because it brings consequences of differences in terms of the types of workers who will take responsibility. The lack of public health personnel, sanitarian and nutritionist can be decrease the performance of field services in the community such as immunization, toddler weighing, home visits, and others services. The lack of pharmacy staff and MLT's has an impact on service quality. An example is the quality of sputum tuberculosis examination, laboratory examinations, etc [11].

This study descript, only $20.2 \%$ PHC's have complete of health worker of promotion and prevention. If seen separately, the ratio of public health workers is 1.8 per PHC's, pharmacy staff is 1.4 per PHC's, nutritionist 1.1 per PHC's, sanitarians 1.0 per PHC's and MLT's 0.7 per PHC's. Many factors contribute to the lack of certain types of health workers in the PHC's. Some studies, national and international references show that $80 \%$ of health success (other than financing) is determined by the number of health workers and the types that have a positive impact on the quality of public health services. In low and middle income countries, lack of understanding of the role of nutrition workers in prevention efforts is the cause of the low availability of nutrition workers in PHC's. Many countries tend to prioritize doctors and nurses.[12]

Public health personnel are one of the health workers who have management knowledge related to public health. Included in the categories as health workers are health epidemiologists, health promotion staff and behavioral sciences, occupational health advisers, health policy and administration staff, biostatistics and population personnel, and reproductive and family health workers. In the PHC's the community health worker is the executive staff for the function of community treatment.[13]

PHC's is one type of first-level health service facility that has an important role in health efforts, which is one of the subsystems in the National Health System (SKN). In carrying out its duties the PHC'S organizes public health efforts and first-level individual health efforts, prioritizing promotion and prevention efforts to achieve the highest degree of public health in its working area. The availability of PHC's staff is an important part of the implementation of health efforts. PHC's staff consists of health and non-health workers in which the number and type of staff are calculated based on workload analysis taking into account the number of services, population and distribution, characteristics of the work area, area of work, availability of other first-level health facilities in the work area, and time division work. However, the government has regulated and determined the number and types of minimum health workers that must be owned by PHC'S contained in Minister of Health (MOH) Regulation Number 75 of 2014. These types of health workers consist of at least primary doctors or doctors, dentists, nurses, midwives, public health personnel, sanitarian, MLT's, nutritionist and pharmacy personnel where the numbers are adjusted according to the category of PHC's based on regional characteristics (urban, rural and remote / very remote PHC's) and the ability to administer (inpatient and non-inpatient).

As it is well known that health service efforts in PHC's prioritize promotion and prevention services, the availability / presence of these service personnel must also be fulfilled to produce optimal services. Based on table 1, the average number of service personnel ranged from 0.67 (MLT's) to 1.84 (public health workers). Based on the minimum labor standards from $\mathrm{MOH}$ regulation number 75 in 2014, the number of each health worker is required at least 1person, except for health workers in urban health centers, nutritionist in all inpatient health centers, and pharmacy personnel in urban inpatient health care centers at a minimum 2 persons. This implies that there are still many types of health workers for minimum standards are not met. The results of Risnakes 2017 show that more than $75 \%$ of PHC's in Indonesia do not meet the minimum labor standards for the full range of promotion and prevention service personnel. MLT's is the most personnel (56.5\%) that is not available at PHC's, then sanitarian, public health personnel, nutritionist and pharmacy personnel. However, public health personnel, sanitarian and nutritionist in PHC's play a role in the implementation of essential community treatment. The low availability of these workers can be an indication that essential community treatment associated with promoting and preventing health problems in PHC's cannot be implemented optimally. The WHO report (2006) mentions that there are 57 countries including Indonesia experiencing a human resources crisis, namely a crisis of health workers in number and distribution. Health workers are currently not able to meet the needs of health services in all regions, especially in disadvantaged, remote, border and island areas.[14]

The government regulation number 2 of 2018 states that the minimum service standard is a provision regarding the type and quality of basic services which is a mandatory government affair that is entitled to be obtained by every citizen at a minimum. Basic services in the minimum service standards (SPM) are mandatory government affairs organized by local governments both provincial and district / city governments.. Health workers in PHC's are the spearhead of implementing programs and health services to the community. This suggests that the adequacy of PHC's services according to minimum labour standards is one of the important indicators in minimum service standards.

\section{Distribution of Promotion and Prevention Health Workers at PHC's in Indonesia}

The distribution of promotion and prevention health workers at the PHC's can be seen in graph 2. South Kalimantan is a province that is fully fulfilled with promotion and prevention personnel at the PHC's more than $50 \%$ followed by North Kalimantan Province. Both provinces have PHC's with more available types of promotion and prevention services compared to other 
provinces. This condition is the same as what was stated by the Center of Planning and Utilization, Board for Development and Empowerment Human Resources of Health,[16] that the problem of imbalance distribution of health workers between provinces, between districts and between PHC's is still an important problem in Indonesia. Based on its population, the PHC's serving more than 30,000 residents, the health suitability of promotion and prevention health workers is higher than the PHC's serving a population of less than 30,000 people. The large number of population served will encourage PHC's to meet their energy needs. This is the same as inpatient and noninpatient health center services. Inpatient health centers have a higher proportion of health workers than noninpatients. When viewed in terms of regional categories, urban health centers have a higher suitability of health workers compared to rural, remote and very remote areas. This is in line with Su'udi et al, that the more remote the suitability of health workers the lower the full health care compared to urban and rural areas when based on the minimum labor standards at the $\mathrm{MOH}$ Regulation number 75 of 2014.[17]

The patterns of financial management (PFM) of PHC's include the Regional Public Service Board (RPSB) and nonRPSB. The results of the study showed that the PHC's implementing patterns of financial management -RPSB had a higher proportion of promotion and prevention health workers compared with the non-RPSB PHC's (Table 2). This is because the patterns of financial will guarantee flexibility in financial management. In addition, those who apply PFM-RPSB are given flexibility in the appointment and dismissal of employees based on the principles of efficiency, economics and productivity in improving services in accordance with Minister of Homes Affairs rules number 61 of 2007.[18] The central government also encourages regional governments to form RPSB. SPSB is a regional work unit or work unit within a local government environment established to provide services to the public in the form of the supply of goods and or services sold without prioritizing seeking profit and conducting its activities based on the principles of efficiency and productivity.[15] The availability of complete promotion and prevention service health worker is also higher in accredited PHC's and those planning HRH needs. Accreditation is mandatory for every PHC's as stipulated in MOH's regulation number 46 of 2015 [19]. The availability of health workers in PHC's is one element in the implementation of accreditation, so that accredited PHC's will be more fulfilled in their personnel. Likewise, a PHC's that has or plans the needs of its health workers will also be more complete.

\section{CONCLUSION}

The complete PHC's has five types of health workers for promotion and prevention services only reach $20.2 \%$ in 2017 under the 2015-2019 Strategic Plan target. The number of promotion and prevention service personnel is 5,600 PHC's in 2019. The distribution of completeness of five types of health workers for promotion and prevention services relates to population, regional categories, service capabilities, financial management patterns and accreditation status, as well as health human resource needs planning. Need strategies for fulfilling health workers, starting from the planning stage of utilization, including in terms of supervision and evaluation, so health workers are distributed evenly throughout all PHC's in Indonesia.

\section{REFERENCES}

[1] Bappenas. Buku II RPJMN 2015-2019: Agenda Pembangunan Bidang. 2015;

[2] Rini T, Lestari P. Analisis Ketersediaan Tenaga Kesehatan Di PHC'S's Kota Mamuju Provinsi Sulawesi Barat Tahun 2014. 2016;75-88.

[3] Gertler PJ, Harimurti P. The Contribution Of Human Resources For Health To The Quality Of Care In Indonesia. :367-79.

[4] Presiden Republik Indonesia. Undang-undang No 36 tahun 2009 tentang kesehatan. 2009.

[5] Kementerian Kesehatan. Peraturan Menteri Kesehatan Nomor 75 tahun 2014 tentang PHC'S's. Jakarta; 2014.

[6] Kementerian Kesehatan. Permenkes RI nomor 44 tahun 2016 tentang manajemen PHC'S's. 2016;

[7] Kementerian Kesehatan. Peraturan Menteri Kesehatan Republik Indonesia Nomor 4 Tahun 2019 Tentang Standar Teknis Pemenuhan Mutu Pelayanan Dasar Pada Standar Pelayanan Minimal Bidang Kesehatan. 2019;

[8] Kementerian Kesehatan. Rencana strategis kementerian kesehatan 2015-2019. 2015;

[9] Badan Penelitian dan Pengembangan kesehatan. Laporan Rifaskes PHC'S's 2011.

[10] Peran Undang Undang Nakes dan Tantangan Masalah Kesehatan Iindonesia. 2014;VI(18).

[11] Ali PB, Siahaan RGM, Solikha DA, Wikanestri I, Ardhiantie, Entos, et al. Penguatan Pelayanan Dasar di PHC'S's [Internet]. 2018. 125 p. Available from: https://www.bappenas.go.id/files/1715/3974/8326/ Buku_Penguatan_Pelayanan_Kesehatan_Dasar_di_ PHC'S's_Direktorat_Kesehatan_dan_Gizi_Masyar akat_Bappenas.pdf

[12] Delisle H, Shrimpton R, Blaney S, Du Plessis L, Atwood S, Sanders D, et al. Capacity-Building for a strong public health nutrition workforce in lowresource countries. Bull World Health Organ. 2017;95(5): 385-8.

[13] Syamsudrajat A, Pentingnya Peran SKM untuk Negri,

2016,https://www.kompasiana.com/agus34drajat/5 70473cee122bdf80de7f8b5/pentingnya-peran-skmuntuk-negeri?page=all. Download 280919; 23.14 pm.

[14] World Health Organization, 2006. The World Health Report 2006: working together for health.

[15] BLUD Atasi Keterbatasan anggaran melalui BLUD Fokus utama, Teropong, Buletin Balitbang Provinsi 
Jawa Timur, Edisi 99, Mei-Juni 2018

[16] Pusat Perencanaan dan Pendayagunaan SDMK Badan Pengembangan dan Pemberdayaan SDM Kesehatan Jakarta, 2018

[17] Su'udi, Amir dkk, 2018, Laporan Hasil Kajian Kesesuaian Ketenagaan di PHC'S's (Analisis Data Risnakes tahun 2017).

[18]Permendagri nomor 61 tahun 2007 tentang Pedoman Teknis Pengelolaan Keuangan Badan Layanan Umum Daerah.

[19] Permenkes nomor 46 tahun 2015 tentang Akreditasi Puskesmas, Klinik Pertama, Tempat Praktek Mandiri Dokter, dan Tempat Praktek Mandiri Dokter Gigi. 